\title{
A autopercepção da comunicação empresarial de colaboradores e a relação com sua saúde pessoal
}

The self-perception of employees' corporate communication and the relationship with their personal health

La auto percepción de la comunicación empresarial de los empleados y la relación con su salud personal

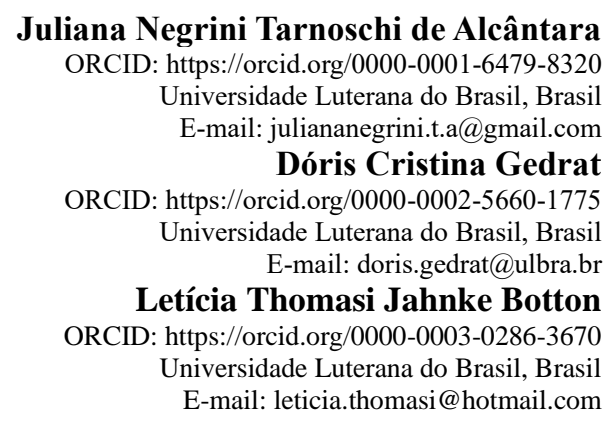

\begin{abstract}
Resumo
A comunicação empresarial vem sendo cada vez mais estudada nas últimas décadas e para que ela ocorra de forma eficaz, é imprescindível que ela flua por todos os departamentos sem ruídos, visto que a comunicação praticada afeta os resultados de toda a empresa. O objetivo da presente pesquisa foi identificar a autopercepção da comunicação empresarial de colaboradores da Empresa $\mathrm{X}$ e a relação desta com a sua saúde pessoal. Para tanto, foi realizado um estudo de caso em uma empresa de produtos alimentícios localizada na cidade de Ji-Paraná, Rondônia. A coleta de dados ocorreu através de entrevistas semiestruturadas, com 13 colaboradores da Empresa X. Para análise dos dados adotou-se o método de Análise de Conteúdo de Laurence Bardin. Os resultados indicam que a comunicação empresarial é vista como positiva pelos colaboradores, apesar de haver rupturas no fluxo comunicacional. O posicionamento de se opor ou contestar um colega é dualista, há os que o fazem com tranquilidade e os que se sentem desconfortáveis em realizar esta atitude. Quanto à autopercepção da saúde, é notável que algumas pessoas entrevistadas observam que há relação do ambiente empresarial com a sua saúde, enquanto outras disseram que não há, apesar de relatarem indicadores que apontam nível de estresse laboral perceptível.
\end{abstract}

Palavras-chave: Comunicação empresarial; Estresse laboral; Percepção da saúde.

\begin{abstract}
Corporate communication has been increasingly studied in recent decades and for it to occur effectively, it is essential that it flows through all departments without noise, since the communication practiced affects the results of the entire company. The objective of this research was to identify the self-perception of corporate communication by employees of Company $\mathrm{X}$ and its relationship with their personal health. Therefore, a case study was carried out in a food products company located in the city of Ji-Paraná, Rondônia. The collection date took place through semi-structured interviews with 13 employees of Company X. For data analysis, the Content Analysis method by Laurence Bardin was adopted. The results indicate that corporate communication is seen as positive by employees, despite disruptions in the communication flow. The position of opposing or contesting a colleague is dualistic, there are those who do it calmly and those who feel uncomfortable in carrying out this attitude. As for the self-perception of health, it is remarkable that some people interviewed note that there is a relationship between the corporate environment and their health, while others said that there is not, despite reporting indicators that point to a noticeable level of work stress.
\end{abstract}

Keywords: Corporate communication; Work stress; Perception of health. 


\section{Resumen}

La comunicación corporativa ha sido cada vez más estudiada en las últimas décadas y para que se produzca de forma eficaz es fundamental que fluya por todos los departamentos sin ruidos, ya que la comunicación practicada repercute en los resultados de toda la empresa. El objetivo de esta investigación fue identificar la autopercepción de la comunicación corporativa por parte de los empleados de la Empresa X y su relación con su salud personal. Por lo tanto, se realizó un estudio de caso en una empresa de productos alimenticios ubicada en la ciudad de Ji-Paraná, Rondônia. La recolección de datos se llevó a cabo a través de entrevistas semiestructuradas con 13 empleados de la Compañía X. Para el análisis de datos, se adoptó el método de Análisis de Contenido de Laurence Bardin. Los resultados indican que los empleados consideran positiva la comunicación empresarial, a pesar de las interrupciones en el flujo de comunicación. La posición de oponerse o impugnar a un colega es dualista, hay quienes lo hacen con calma y quienes se sienten incómodos en llevar a cabo esta actitud. En cuanto a la autopercepción de la salud, es destacable que algunas personas entrevistadas señalan que existe una relación entre el entorno empresarial y su salud, mientras que otras afirman que no, a pesar de reportar indicadores que apuntan a un marcado nivel de estrés laboral.

Palabras clave: Comunicación empresarial; Estrés laboral; Percepción de salud.

\section{Introdução}

No último século, o mundo presenciou um avanço tecnológico cada vez mais rápido, e no campo empresarial não foi diferente. Nesse sentido, Chiavenato (2000) aborda como as teorias administrativas evoluíram acompanhando o avanço dos tempos e como o modo de gerir empresas foi se adaptando às inovações tecnológicas e se aprofundando no setor de serviços, o que levou as empresas a adotarem novos métodos de gestão. Assim, os métodos passaram de mecanicista, com foco nos tempos e movimentos, para uma gestão muito mais voltada à humanização de processos e valorização do capital humano nas organizações. A comunicação permitiu, portanto, interatividade entre os grupos humanos e conduziu a sociedade gradativamente para o progresso pela transmissão do conhecimento (Oliveira, Damião, Oliveira, \& Nogueira, 2020).

Todas as partes de uma organização têm impacto em sua gestão, pois funcionam como engrenagens de uma grande máquina: as condições salariais e laborais, o ambiente em que o trabalho é realizado, as inter-relações hierárquicas, etc. Igualmente está a compreensão de que trabalhadores motivados gerarão mais e melhores resultados, sendo essencial para que haja a mediação entre estes dois lados (líderes e liderados), uma boa comunicação (Marques, 2018). Desse modo, a comunicação pode ser a chave para proporcionar a motivação, o bem-estar e promover a saúde da equipe ou fazer com que haja desunião, desavenças, confrontos negativos e até o adoecimento da equipe.

Há autores que utilizam a terminologia "comunicação organizacional" no que concerne ao tema desta pesquisa, entretanto, para este estudo optou-se por utilizar a nomenclatura "comunicação empresarial", seguindo o modelo proposto por Bueno (2003), referência em estudos na área da comunicação, especialmente da comunicação em empresas.

Antes de se iniciar a conceituação acerca da comunicação, se faz necessária a ponderação da diferença entre comunicação e informação. Cortes, Nunes, Ernesto, Martins e Souza (2018) trazem a comunicação como sendo um fenômeno que envolve a percepção, isto é, é interpessoal, requer que o receptor-usuário seja alguém que faça alguma coisa ou acredite em alguma coisa. Já a informação é "puramente" formal, não tem significado, é impessoal, e quanto mais ela se afasta do “componente humano” (emoções, valores, expectativas e percepções), mais apropriada e genuína é, mais informativa. Dessa maneira, a informação pressupõe a comunicação.

Matos (2004, p. 27) comenta que a palavra "comunicação" é “originada do latim communicare, que significa "tornar comum', 'partilhar', 'repartir', 'associar', ‘trocar opiniões', ‘conferenciar’”, assim, “a comunicação é a força que movimenta a vida das pessoas, das empresas e das sociedades”. Por estar presente em todos os ambientes, é através da comunicação que nos relacionamos, aprendemos, ensinamos e evoluímos como seres humanos sociais. E, dentro de uma organização, a comunicação, quando bem utilizada, pode estabelecer relações pacíficas, homogeneização e integração de ideias. Montes (2020) destaca que a comunicação é um processo dinâmico, pelo qual informações são trocadas entre pessoas, por meio de um sistema comum de 
símbolos, sinais e comportamentos. Torquato (1991, p. 162) cita ainda que "a comunicação é uma ferramenta importante de eficácia e produtividade".

Em especial a comunicação empresarial compreende:

[...] um conjunto complexo de atividades, ações, estratégias, produtos e processos desenvolvidos para criar e manter a imagem de uma empresa ou entidade (sindicato, órgãos governamentais, ONGs, associações, universidades etc.) junto ao seus públicos de interesse (consumidores, empregados, formadores de opinião, classe política ou empresarial, acionistas, comunidade acadêmica ou financeira, jornalistas etc.) ou junto à opinião pública (Bueno, 2003, p. 40).

Dessa forma, quando os colaboradores de uma empresa trabalham em grupos, a comunicação não se restringe aos meios formais e tampouco ao foco do trabalho ou atividade. No cotidiano empresarial, os colaboradores desenvolvem canais informais para compartilhar informações, podendo desenvolver boatos ou as chamadas "rádio peão" ou "rádio corredor", que são as informações passadas boca-a-boca (Chiavenato, 2000).

Os elementos que envolvem a comunicação, de modo geral, de acordo com Marques (2018), são quatro: 1) emissor, que é o responsável por transmitir a mensagem com todas as informações necessárias para que haja o entendimento assertivo e efetivo desta; 2) receptor, que é quem recebe a mensagem e faz a sua interpretação; 3 ) linguagem, que são os códigos de linguagem que são utilizados para que haja a transmissão correta das informações; 4) e mensagem, que é basicamente o conjunto de informações que são transmitidas.

A função da comunicação, para Beltrão e Beltrão (1993, p. 15), é o fato de que "toda comunicação visa estabelecer relações e somar experiências. Em última análise, tem por objetivo a troca de informações entre fonte e destino". Bordenave (1995, p. 45) complementa ao dizer que "a comunicação é um produto funcional da necessidade humana de expressão e relacionamento".

Nesse sentido, o modelo tradicional para desenvolver uma comunicação eficiente, de acordo com Kotler (1998, p. 12), deve ter nove elementos fundamentais: 1) emissor: quem emite a mensagem para a outra parte; 2) codificação: o processo de transformar o pensamento em forma simbólica; 3) mensagem: o conjunto de símbolos que o emissor transmite; 4) mídia: os canais de comunicação pelos quais a mensagem passa do emissor ao receptor; 5) decodificação: o processo pelo qual o receptor confere significado aos símbolos transmitidos pelo emissor; 6) receptor: quem recebe a mensagem emitida pela outra parte; 7) resposta: as reações do receptor após ter sido exposto à mensagem; 8) feedback: a parte da resposta que o receptor devolve ao emissor; 9) e ruído: distorção ou estática não planejada durante o processo de comunicação que resulta em uma mensagem chegando ao receptor diferentemente da forma enviada pelo emissor.

O modelo de Kotler (1998) é defendido e adaptado também por outros autores, contudo, em geral, quatro são os elementos mais abordados na literatura da área: emissor, mensagem, receptor e feedback. Nessa perspectiva, "Quando um desses elementos não é respeitado, o processo de comunicação enfrenta problemas difíceis de serem diagnosticados, que podem trazer sérios danos aos objetivos e resultados da empresa" (Kotler, 1998, p. 12).

A utilização da comunicação ocorre, na maior parte das vezes, de forma inconsciente, e muitas vezes sem levar em consideração se quem está recebendo está apto para decodificar e compreender a mesma. Assim, “A comunicação é uma via de mão dupla e, portanto, não basta preocupar-se apenas com o seu comportamento sem levar em consideração a realidade daquele com quem você interage" (Kyrillos \& Jung, 2015, p. 26).

Neiva (2018) destaca três dimensões da comunicação empresarial: 1) a dimensão instrumental, que visa o controle da produção e da eficácia dos indivíduos nas organizações; 2) a dimensão estratégica, que visa a adaptação ao ambiente pelo tempo através da definição de estratégias adequadas para alcançar objetivos da organização; 3) e a dimensão humana é, considerada a mais importante e a mais esquecida, não só na literatura, mas também nas práticas cotidianas. A autora pondera ainda que “a 
dimensão instrumental e estratégica parte de uma visão funcionalista e linear da comunicação", enquanto a dimensão humana está voltada para as relações que são “construídas e reconstruídas no dia-a-dia das organizações” (Neiva, 2018, p. 64).

A comunicação nas organizações, além do já exposto, pode também estar relacionada aos aspectos interpessoais, organizacionais e sociais, bem como aos processos, pessoas, mensagens e significados (Marchiori, 2011). Trata-se de um processo de se relacionar com outros indivíduos, departamentos, fornecedores, pessoas de outras unidades e organizações. Colocando em análise este processo relacional da comunicação do dia a dia dentro das organizações, a comunicação, tanto interna quanto externa, sofre interferências e é condicionada de formas variadas, compreendendo uma complexidade difícil até de ser diagnosticada, tendo em vista a quantidade de diferentes tipos de comunicação existentes que atuam nos distintos contextos sociais (Kunsch, 2006).

Ainda sob a luz desse paradigma relacional, Lima (2015, p. 39), amparada em outros autores, entende as organizações “como um ator social coletivo", estas são, então, "constituídas por sujeitos que estão em constante relação e interação, enquanto a comunicação se configura como a mediadora e organizadora desses processos de interação". Assim, a comunicação completa e eficaz, entendida como o fornecimento ou troca de informações, ideias e sentimentos através da palavra escrita ou oral ou de sinais, é indispensável para o ajuste das pessoas dentro de uma organização (Takahashi \& Pereira, 1991).

Vale ainda destacar que o ambiente organizacional, como é visto hoje, é relativamente novo, pois foi estruturado e moldado há poucas décadas, e por este fator e pelos demais supracitados, entende-se que estudar como a comunicação acontece dentro de uma empresa e o impacto que ela causa em seus colaboradores, agregará para o entendimento e aprimoramento dos processos comunicacionais internos. Para Matos (2004, p. 2), “a comunicação é o fio condutor de todas as atividades e relacionamentos humanos. Literalmente nada acontece sem que haja prévia comunicação.” Por isso a importância de estudar como esta é percebida pelos colaboradores, para que a partir desta análise seja possível identificar fatores de melhorias que possibilitarão maiores resultados para a equipe e, consequentemente, para a empresa. Nesse cenário, outras características surgiram com o avanço do ambiente organizacional:

A rotina e a invariabilidade das tarefas trazem o sofrimento e esse, consequentemente, o adoecimento. Porém, não é apenas espaço de tempo que o trabalho ocupa na vida das pessoas. Para muitas pessoas, o trabalho é o fator central de sua vida, é o que dá significado a ela [...] Ele ocupa um espaço de investimento afetivo, de dedicação, de investimento financeiro, de realização pessoal (Bertoldi, 2013, p. 161).

Cardoso e Morgado (2019) salientam que há uma forte resistência social em reconhecer que o colaborador pode sofrer consequências como mal-estar, doenças e acidente de trabalho, e que é em detrimento dos interesses envolvidos o que leva a sociedade a querer esconder o adoecimento no trabalho. Sabendo disso, se faz a importância de estudar mais como os colaboradores podem ser afetados em ambientes empresariais. Bertoldi (2013, p.168) aborda que dentre as principais doenças relacionadas ao trabalho, estão "os transtornos mentais, tais como: depressão, ansiedade e síndrome do pânico", e os físicos, como: "os distúrbios osteomusculares, como a LER; cardiopatias; dores crônicas e problemas circulatórios", destacando que, para além das doenças físicas, deve-se dispensar desmedida atenção às doenças mentais.

Diante dessa demanda por compreender mais da comunicação empresarial e sua relação com a saúde do colaborador neste ambiente, esta pesquisa teve como objetivo identificar a autopercepção da comunicação empresarial de colaboradores da Empresa $\mathrm{X}$ e a relação da mesma com a sua saúde pessoal.

\section{Metodologia}

No âmbito da presente pesquisa e a fim de avançar no estudo da temática da comunicação empresarial, sua autopercepção por parte de seus colaborares e a relação com a saúde, realizou-se um estudo de caso único e instrumental, pois a 
análise permitiu a compreensão de um assunto geral. Este estudo caracteriza-se como descritivo, com abordagem qualitativa e como uma pesquisa empírica que investiga um fenômeno contemporâneo no contexto da vida real e que pode ser adequada a entidades como grupos sociais, comunidades, instituições ou organizações.

A pesquisa foi realizada em uma organização de médio porte do ramo industrial alimentício, a qual possui a sua sede na cidade de Ji-Paraná, Rondônia. Foram convidados a participar da pesquisa pessoas que trabalham no administrativo da Empresa X. A empresa possui em média 160 colaboradores, foram entrevistados e selecionados para esse estudo 13 colaboradores.

As pessoas entrevistadas foram identificadas como E1, E2, E3 e por diante até E13, não se utilizando de nome, cargo ou outra característica, a fim de preservar o anonimato das mesmas e não gerar possíveis constrangimentos para participantes da pesquisa. Igualmente, a menção é feita no feminino se referindo às pessoas entrevistadas, sem conotação de gênero.

A pesquisa teve como critérios de inclusão: trabalhar na empresa há mais de seis meses, tempo mínimo e razoável para o funcionário se adaptar à rotina, normas e cultura organizacional, atuar no setor administrativo e ter relação de comunicação direta com os pares. Já os critérios de exclusão foram: trabalhar fora do prédio administrativo, estar há menos de seis meses na empresa em março de 2021, atuar no papel de líder do setor e não ter relação direta com o fluxo comunicacional. Igualmente, foram excluídos da amostra os cidadãos que se recusam a responder qualquer um dos itens da pesquisa, os que estavam de licença, férias ou ausentes na empresa, por algum motivo, nos dias da coleta de dados.

Para a análise dos dados obtidos foi realizada a técnica de Análise de Conteúdo de Bardin (2011), muito usada em pesquisas qualitativas como o presente estudo, a qual é composta de três etapas: pré-análise, exploração do material e tratamento dos resultados. Na etapa de pré-análise foi feita a leitura flutuante das entrevistas e o preparo do material. Na exploração do material foram criadas as categorias de análise, a saber: 1) autopercepção positiva e negativa da comunicação empresarial; 2) comunicação como contestação e/ou oposição; 3) autopercepção da relação entre a comunicação empresarial e sua saúde pessoal. E, em seguida, foi realizado o tratamento dos dados construindo uma análise do material coletado.

A pesquisa seguiu todas as recomendações da Resolução nº510 (2016), do Conselho Nacional de Saúde, e a coleta de dados foi iniciada depois da aprovação na Plataforma Brasil com o Certificado de Apresentação de Apreciação Ética (CAAE) $\mathrm{n}^{\circ}$ 45574121.4.0000.5349, e mediante assinatura do Termo de Consentimento Livre e Esclarecido (TCLE) por cada uma das pessoas participantes.

\section{Resultados e Discussão}

Todos as pessoas entrevistadas participantes desta pesquisa trabalham na parte administrativa do parque industrial, entre elas: técnica contábil, encarregada de contabilidade, auxiliar de contabilidade, assistente financeira, encarregada de Recursos Humanos, auxiliar de escritório, contínuo e faturista. Estas foram selecionadas pelo proprietário da Empresa X de acordo após conversa preliminar para sondagem do ambiente alvo do estudo. Foi utilizada a entrevista semiestruturada com um roteiro previamente definido, podendo ter sofrido pequenos ajustes no momento da entrevista, conforme necessidade e o roteiro de perguntas foi elaborado especificamente para este projeto.

O perfil das pessoas participantes da pesquisa se caracterizou por profissionais entre 28 e 35 anos de idade, sendo um grupo relativamente jovem para ocupar a parte administrativa da empresa. Quanto à escolaridade, a maior parte possui Ensino Superior completo ou incompleto, o que demonstra o reconhecimento da Empresa $X$ em valorizar o estudo acadêmico.

As participantes da pesquisa possuíam em média oito anos e meio de trabalho na Empresa $\mathrm{X}$, enquanto a média de tempo de trabalho total, considerando toda a experiência profissional, foi de treze anos e meio; sendo que a pessoa que estava com menos tempo de trabalho na referida empresa era de um ano e a mais antiga possuía vinte anos trabalhando na mesma 
empresa (tendo sido sua única experiência profissional e durante a entrevista relatou que foi crescendo de cargo dentro da empresa no decorrer dos anos). Para várias pessoas, o trabalho na empresa representa a maior parte da experiência profissional que já tiveram. Portanto, todas as participantes da pesquisa possuíam vivência e ambientação à cultura organizacional.

Como definido por Lück (2010, p. 71), a cultura organizacional apresenta-se como:

[...] conjunto de pressuposições básicas, que um grupo inventou, descobriu ou desenvolveu ao aprender como lidar com os problemas de adaptação externa e integração interna, e que funcionou bem o suficiente para serem considerados válidos e ensinados a novos membros como a forma correta de se perceber, pensar e sentir em relação a esses problemas.

Desse modo, a relação do trabalhador com seu trabalho pode ser positiva ou negativa, cabendo questionar: quando o trabalho poderia ser considerado “fonte de promoção de doença, e não promotor de saúde física e/ou mental?" (Bertoldi, 2013, p. 179). A resposta a esta questão se coloca na autopercepção de colaboradores da Empresa X, sendo a comunicação empresarial aspecto determinante. Assim, as categorias de análise estabelecidas a partir dos dados coletados em entrevistas, isto é, a autopercepção de colaboradores sobre a comunicação empresarial e sua relação com suas saúdes, seguem aprofundadas a seguir.

\section{Autopercepção positiva e negativa da comunicação empresarial}

Como abordado anteriormente, a comunicação empresarial é o processo natural de se relacionar com outros indivíduos no ambiente empresarial, e com outros departamentos, fornecedores, pessoas de outras unidades e organizações (Marchiori, 2011; Matos, 2004). Kunsch (2006) complementa que a comunicação tem que ser entendida como parte inerente à natureza das organizações e que sem a comunicação as organizações não existiriam.

Apesar de não estar nos objetivos do estudo identificar por quais meios ocorre a comunicação da Empresa X com seus colaboradores, na primeira entrevista foi narrado como ela mais acontece, conforme o relato abaixo pela entrevistada E1:

A maioria da comunicação hoje da empresa com o restante, é via WhatsApp. A gente tenta colocar visualmente, que é colocar recado no mural, o nosso mural é próximo ao ponto, então a gente coloca lá e a maioria nem sabe o que tá lá, bate ponto e nem olha o que tá ali, principalmente o pessoal do escritório, o pessoal do escritório é a maioria que não lê, só vai lá bate ponto e não lê, então pra dar esse tipo de recado a gente achou melhor fazer tudo via WhatsApp, porque hoje todo mundo tem acesso ao WhatsApp, então a gente faz a nossa comunicação com os demais funcionários via WhatsApp.

Nessa fala é notável que o canal de comunicação não está adequado, uma vez que as mensagens escritas e afixadas não são lidas, em contrapartida, as mensagens virtuais pelo aplicativo são decodificadas corretamente e respondidas. Como conceituado por Bertoldi (2013, p. 109), o canal “é o veículo ou a mídia pela qual a mensagem é encaminhada. É o portador da mensagem e é selecionado pelo emissor”. Complementando ainda, Brum (2000) defende que ao disponibilizar uma informação, isso não representa por si só que houve a comunicação. Assim, toda vez que se lança um canal de comunicação é necessário que se faça a sua divulgação; é preciso motivar o funcionário a acessá-la. A responsável pela comunicação é a direção, mas isso não impede que ela seja dividida com parceiros das mais diversas áreas.

Por outro lado, esse cenário demonstra a capacidade de percepção e adaptação da empresa quando adequou o canal de comunicação para os meios digitais e, com isso, teve maior efetividade no processo. Nesse mesmo sentido, durante a pandemia COVID-19 ao longo dos anos de 2020 e 2021, a Empresa X transformou a Semana Interna de Prevenção à Acidentes de Trabalho (SIPAT), que consistia em cursos e palestras presenciais reunindo todos os colaboradores no auditório, para vídeos e panfletos transmitidos também via Whatsapp.

Ainda nessa esteira, é importante destacar que o objetivo principal deste artigo foi observar a autopercepção que 
colaboradores tinham da comunicação empresarial. Percepção aqui entendida como "a capacidade de associar as informações captadas pelos órgãos dos sentidos à memória e à cognição de modo a formar conceitos sobre o mundo e sobre nós mesmos e orientar nosso comportamento" (Lent, 2005, p. 556). Bertoldi (2013, p. 37) diz ainda que "é o processo de percepção que transforma a realidade em um padrão que as pessoas reconhecem. A percepção é uma interpretação singular da situação ou estímulo". Portanto, em se tratando de percepção, não existe o certo e o errado, mas sim como a pessoa associou os eventos ocorridos com o padrão que ela já possuía. Chiavenato (2005) afirma que o que as pessoas interpretam como realidade não é a realidade, mas uma representação desta.

Quando questionadas nas entrevistas sobre como percebiam a comunicação na Empresa X, a comunicação empresarial, mesmo com percalços, foi descrita como positiva e satisfatória. E5 disse que "minha comunicação com os colegas de trabalho é boa, converso com todo mundo, brinco com todo mundo, todo mundo brinca comigo" se referindo ao bom relacionamento com colegas de trabalho. E4 narra de forma bem semelhante dizendo que "aqui dentro da empresa, eu vejo que a comunicação é boa, é ótima, eu tenho um convívio muito bom com meus colegas de trabalho". Algumas pessoas narraram que é perceptível a melhoria no processo comunicacional da Empresa X, E1 explica que "a gente já foi muito fraco mesmo na comunicação" e a E10 complementa essa afirmação ao alegar que: "Melhorou muito, a gente acaba arrumando [...] nós temos muita ruptura, melhoramos muito, mas nós estamos no caminho".

Ao compararem-se as falas, observa-se, contudo, uma distorção do processo perceptivo, que intercorre quando a informação ambiental é captada ou interpretada de forma alterada (Bertoldi, 2013). Como foi o caso de E9, que se demonstrou destoante do restante dos entrevistados quando foi categórica ao afirmar que a comunicação "não funciona", pois a mesma se sente prejudicada quando alguns processos que eram para ser rotineiros não são feitos e/ou são esquecidos, e isto afeta diretamente o seu trabalho.

Mesmo com a perspectiva de melhoria constante citada acima por E1 e E10, é notável que ainda há muitos ruídos na comunicação, como o exemplo de retenção de informação citado por E2: "Às vezes a gente comunica com um e aí a pessoa não passa pra frente, então atrapalha todo o serviço". E1 também confirmou tal situação dizendo que: "O ponto negativo que eu acho é a questão de reter informação", justificando que às vezes é por esquecimento da pessoa que deveria ter passado a informação, deixando a entender que a pessoa sabia da obrigatoriedade em comunicar, entretanto, deixou para outro momento e esqueceu. Esta percepção da falha de comunicação pelo esquecimento também foi narrada por E14 da seguinte forma: "Às vezes falta um pouco de comunicação, mas às vezes é esquecer mesmo, se esquece de me passar alguma coisa”. Essas duas formas de comunicação, a interpessoal e a intrapessoal, estão diretamente ligadas ao sucesso do feedback, uma vez que:

Se não houver uma boa resolução interna, por meio da organização dos pensamentos, também não haverá uma boa comunicação interpessoal, gerando [...] ruído na comunicação e falta de disposição para ouvir o que o outro tem a dizer. Isso poderá gerar conflitos e rompimento das relações pessoais e profissionais (Silva \& Machado, 2017, p. 48).

Um dos pontos de encontro que aparece em diversas entrevistas, observado em muitas falas, foi a narrativa de quebra de hierarquia ou quebra de fluxo original da informação, isto é, ela não segue o fluxo que deveria, passando hierarquicamente pelos responsáveis até chegar aos respectivos subordinados aos quais ela se destina. Durante as entrevistas, em algumas narrativas envolvendo nomes e cargos foram narradas algumas histórias que exemplificam como se "pulam" algumas pessoas no meio do caminho e como isso gera descontentamento da equipe. Este fato foi narrado por diversas pessoas em cargos diferentes, caracterizando assim uma cultura empresarial existente que é defendida por alguns como ponto positivo, o "livre acesso", e como ponto negativo por outros, em que acaba acontecendo esses "atropelos" no fluxo da informação. A fala da entrevistada E2 denota esse apontamento: 
Um ponto negativo, que eu acho que às vezes acaba atrapalhando muito é a respeito da hierarquia. Respeitar não só a gente, mas os superiores também; tipo, designar a pessoa pra fazer tal coisa, então confiar na minha pessoa, não atropelar o que a pessoa tenta fazer, porque, às vezes, são entre as pessoas dando ordem e a pessoa que a gente, por exemplo, falam que é a pessoa que tem que cuidar e organizar aquele setor lá na indústria, e aí a gente vai tentar conversar com essa pessoa, mas os chefes já deram outras ordens, então, às vezes fica uma falta de comunicação, falta de confiança por todo mundo ter acesso a tudo, talvez seja isso. [...] ter acesso a todo mundo, às vezes, pula uma etapa das pessoas que têm na diretoria, os cargos e hierarquia, pula uma coisa ou outra, e acaba atropelando as coisas.

Esta mesma situação foi trazida em várias narrativas, como a de E10, que exemplifica situações que vivenciou dizendo ainda que: "isso acontece com muita frequência!” e que "tudo da comunicação, alguém vai receber uma ordem e alguém deu a ordem, e no meio alguém pode sofrer com a falta da informação", concluindo que por conta deste tipo de situação "a pessoa no meio do caminho fica um pouco perdida", se referindo à pessoa que foi excluída do fluxo da informação. E10 ainda se mostrou prestativa dizendo que "se eu sentir onde é que tá e for da minha capacidade, eu vou ajudar na hora". E13 comenta sobre isso descrevendo como informação desencontrada, e que:

Às vezes um fala uma coisa, aí outro vem e fala outra, mas nem sempre acontece, mas acaba acontecendo de algum problema que aconteceu, aí um vem e fala que aconteceu tal coisa, aí outro vem e fala que era diferente, a gente fica meio perdida.

Em quase todas as entrevistas, as pessoas participantes alegaram que possuem acessibilidade aos superiores, visto como aspecto positivo. E4 enfatizou positivamente que em outra empresa em que trabalhava não era assim. E6, E7, E8, E10 e E14 comentam sobre esta proximidade com os superiores e E7 complementa dizendo que o livre acesso é a todos do setor administrativo.

Brum (2000) relata que para a comunicação gerar impacto no comportamento do funcionário, o estímulo precisa obedecer a três dimensões específicas: personalização, interatividade e impacto sensorial. A personalização é a forma como a informação é ajustada em suas características de acordo com o público a qual se destina. O nível de interatividade depende da velocidade e do incentivo ao retorno que a comunicação interna provoca no funcionário. O nível de impacto sensorial torna-se alto quando o funcionário pode ver, ouvir, sentir, cheirar e experimentar a informação. Este estímulo é muito utilizado para lançamento ou desenvolvimento de novos produtos com o fim de proporcionar o pertencimento a todos na empresa levando-os a se sentirem parte do processo de criação.

Mesmo com o fácil acesso aos superiores e a comunicação sendo percebida como majoritariamente positiva, para que cada colaborador cumpra o seu trabalho é necessário autonomia para desempenhá-lo. Bianco (2000, p. 140) conceitua autonomia como sendo: "Competência humana em seguir suas próprias leis, ou ainda, pessoa capaz de fixar normas de sua conduta. No entanto essa autonomia não é absoluta e sim relativa, pois depende do querer dos outros e da sociedade em que se vive". Em concordância, E11 comentou em entrevista:

[...] acho que a comunicação aqui sempre foi bem clara, cada um tem a noção do seu trabalho, e eu acho que tem aquela situação de liberdade também, então todo mundo sabe o que tem que fazer, e tem a sua comunicação, mas tem a liberdade pra poder fazer o seu trabalho sem ficar aquela pressão em cima, eu acho que isso é a parte boa.

Com esta fala de E11 é notável que há tal autonomia para desempenho das funções na Empresa X. Em contrapartida, a ruptura no fluxo de informação também foi notada, como narrado por E2 anteriormente ao comentar que o superior passa a demanda para o responsável comunicar o encarregado da execução e antes que o responsável transmita a informação o próprio superior vai até o encarregado e fala o que quer, pulando assim o intermediário. Tal situação foi descrita por E2 como falta de 
confiança em seu papel, quando lhe é tirada a autoridade de lidar com a equipe e sua autonomia em gerir os seus processos, gerando assim insatisfação.

\section{Comunicar contestação e/ou oposição aos seus colegas de trabalho}

Mesmo com a facilidade de acesso aos superiores, conforme narrado diversas vezes anteriormente, ainda assim algumas pessoas entrevistadas mostraram-se desconfortáveis em contestar, apontar erros de colegas e/ou se opor à alguma situação, conforme é possível identificar nos trechos extraídos das entrevistas a seguir.

E1 alega que "é bem desconfortável, bem desconfortável mesmo"; E2 descreveu que quando é com colegas é mais fácil, entretanto "quando é o superior, é mais difícil, às vezes você não fala, porque é o meu serviço, né?"; e E13 comentou que: "Geralmente eu não confronto líder; geralmente me pedem explicação de algum erro".

E3, por outro lado, colocou que: “dependendo da situação eu me sinto incomodada, eu me sinto no dever de me posicionar", evidenciando que se posiciona quando necessário e comenta que tenta falar de modo que a pessoa entenda e que não se sinta oprimida pelo apontamento feito por ela. Do mesmo modo, E4 expõe em sua fala que "é um pouco constrangedor", demonstrando que mesmo não sendo confortável ela fala quando precisa, e finaliza dizendo: "mas para o melhor da empresa a gente sempre tem que tá atento, né?", o que demonstra que mesmo sentindo desconforto contesta ou se opõe a algum colega ou superior sobre possíveis erros pensando no bem da empresa.

Em conformidade com E4, E8 relatou o mesmo comportamento quando comenta: “às vezes pode até ocorrer alguma coisa, mas são coisas que são necessárias dentro da empresa”, e diz que às vezes pode ficar meio cabisbaixa com alguma situação, mas que é dentro da normalidade das situações que ocorrem no meio empresarial. Da mesma forma, E9 é categórica em dizer que "é necessário, tem que ser feito! [...] eu não gosto de me indispor com ninguém, mas também não vou deixar a coisa errada acontecendo".

Contudo, E9 alega ainda que: "Eu não gosto, eu fico um pouco irritada", defendendo posteriormente que não leva para o pessoal, entende que é tudo profissional, apesar de pensar que uma vez que foi ensinado como fazer o seu trabalho, não seria preciso outra pessoa ficar cobrando ou corrigindo. Ainda assim, E9 pondera: “mas, assim, a gente tem que falar incansavelmente inúmeras vezes; saber que a gente tá lidando com vários tipos de pessoas e de entendimentos, também tem que ser compreensível, né?", indicando também a compreensão de que nem todas as pessoas aprendem com a mesma facilidade.

De acordo com Ministério da Saúde e Organização Pan-Americana da Saúde (2001, p. 161) em seu manual de procedimentos para os serviços de saúde quanto a doenças relacionadas ao trabalho, "Ambientes que impossibilitam a comunicação espontânea, a manifestação de insatisfações, as sugestões dos trabalhadores em relação à organização ou ao trabalho desempenhado provocarão tensão e, por conseguinte, sofrimento e distúrbios mentais".

À vista disso, fica mais notável a importância de poder se expressar espontaneamente. Não obstante, dentre as pessoas entrevistadas, E3 foi a única que comentou sobre uma possível seletividade por tempo de serviço:

Eu acho que algumas pessoas têm mais voz, tipo assim, mesmo sendo do mesmo setor; por exemplo, eu tenho três anos, fulano tem sete, então eu acho que às vezes eles dão mais crédito para o que tem sete que fala do que para o que tem três.

Em contrapartida, algumas das pessoas entrevistadas alegaram não ter desconfortos em comunicar contestação e/ou oposição em relação aos seus colegas. E14 descreve que não tem problemas para se comunicar quanto às coisas que ela identifica que estão certas ou erradas, pois a mesma diz ter liberdade para falar com todos na empresa. Na entrevista, E2 colocou que: "às vezes eu saio de chata, de nervosa, mas eu não gosto de deixar as coisas passar, que é pra fazer tudo o mais certo possível”. Já 
E5 colocou da seguinte forma: “eu acredito que eu sou bem tranquila pra falar”. Enquanto E10 definiu como sendo "necessário, tem que ser feito, você entendeu?”. E11 igualmente se mostrou tranquila para descrever como lida com situações em que precisa contestar sem que isso lhe gere desconforto:

Dependendo do que for eu já vou fazer de imediato, eu não tenho desconforto não. Tranquilo. Dependendo do que for eu vou tratar e sem rodeios também. E se der um conflito, se der um atrito, pra mim aquilo dali é algo que acabou, acabou também, não vou ficar chateado não [...] muitas das vezes o conflito gera solução.

Entretanto, esta realidade não é a da maioria das pessoas entrevistadas, como pôde ser observado anteriormente. Alguns demonstraram desconforto ao precisar contestar ou se opor, mesmo assim a maioria defendeu a posição de que se for preciso, fazê-lo.

\section{A autopercepção dos colaboradores sobre a relação entre a comunicação empresarial e sua saúde}

Para iniciar esta etapa da entrevista, foi solicitado às pessoas entrevistadas que descrevessem como percebem sua saúde atual. Para este estudo é utilizado o conceito de saúde como sendo "um construto complexo que abarca bem-estar e funcionalidade nas diversas áreas da vida em termos físico, mental, emocional e social, entre outros" (Souza, Alves, Câmara, Aerts, \& Gedrat, 2019, p. 109); já quanto a percepção da saúde:

A percepção de saúde pessoal corresponde a uma avaliação geral de como a pessoa percebe sua própria saúde. A partir de definições pessoais sobre ela, as pessoas avaliam subjetivamente como se sentem e quais os aspectos primordiais relacionados. A avaliação subjetiva e individual de saúde tem se mostrado válida e confiável por apresentar estabilidade temporal (Souza, et al., 2019, p. 109).

Algumas das pessoas entrevistadas descreveram como percebem a sua saúde em detalhes, enquanto outras não responderam diretamente, mas falaram sobre algum aspecto de sua saúde ou sobre alguma doença que possui. E3 descreveu sua saúde como "a saúde está tranquila"; E9 foi bem otimista colocando que "de saúde eu estou bem. Física, mental, tá tudo controlado". A entrevistada E13 relacionou sua saúde com prática de atividades físicas ocasionais e ausência de doença da seguinte forma: "Uma vez na vida outra na morte faço uma caminhada. Mas é boa, dificilmente eu fico doente". Já E8 disse: “eu teoricamente penso que a minha saúde tá boa”, e em seguida a entrevistada narra situações particulares de familiares doentes e de mortes na família recentes e depois complementa:

[...] então, assim, a gente dá aquele baque na sua saúde mental, né? Mas a sua parte de estrutura física e tal, graças a Deus, tá dentro da normalidade, mas essa parte mental dentro dessa situação a gente fica um pouco amuado, mas nada que a gente não consiga, assim, trilhar um norte e bola pra frente, a gente sabe que não é fácil, mas a gente tem que lutar.

Das entrevistadas que descreveram alguma doença existente ou contextualizaram o histórico, duas chamam a atenção. A primeira foi E14, uma sobrevivente da COVID-19 que relatou as sequelas após se contaminar e desenvolver a doença duas vezes em poucos meses de intervalo. Dentro da sua narrativa ela falou que ainda não se recuperou totalmente, que ainda se encontrava fadigada, "mas nada que interfira no trabalho nem nada não" e ainda que "meu problema mesmo foi o fígado [...] porque eu fiquei um mês e pouco assim, com um amargo na boca [...] E um pouco dor de cabeça que eu sinto quase todo dia. Mas só, nada que interfira no trabalho”. Apesar do relato de não interferência, é questionável que alguém que sinta dores de cabeças diárias verbalize que isso não interfere no seu trabalho, visto que gera desconforto e desgaste sentir dores diárias.

A segunda entrevistada que descreveu um problema de saúde mais preocupante foi E10, que explicou como recebeu 
um diagnóstico de infarto após sentir dores no peito por alguns dias, mas que continuou trabalhando sem ir buscar auxílio médico de imediato, quando o fez precisou ficar internado para procedimentos imediatos e precisou se recuperar na UTI por uns dias, e ainda que em virtude disso teve que fazer ajustes em sua rotina e na dieta, e que já emagreceu 10 quilos em quase seis meses desde o ocorrido. Ela discorreu sobre algumas situações pessoais, familiares e empresariais que estavam lhe preocupando e que, somada à falta de cuidado com sua saúde e alimentação, acabaram ocasionando no infarto; e finalizou sua narrativa comentando que a "saúde mental tá bem razoável de maneira geral, corporal eu tô voltando gradativamente conforme as orientações médicas".

Ao referirem sua percepção de saúde, algumas entrevistadas indicaram que procuram cuidar de sua saúde preventivamente, alguns com exames periódicos ofertados pela Empresa X e mais os particulares, como indicado pela pessoa entrevistada E7, e outras relacionando as atividades físicas realizadas, como E11. E só de ter sido perguntada sobre o assunto, E5 colocou que: "Sou sedentária, tenho que voltar a correr, tenho que voltar a caminhar", demonstrando que se preocupa com a importância da atividade física, apesar de não a estar praticando no momento.

Contudo, em relação à saúde dos colaboradores exclusivamente no ambiente empresarial, foi possível perceber, principalmente, queixas relacionadas ao estresse, como na fala de E3:

[...] a saúde tá tranquila, mas às vezes talvez algum estresse do dia a dia, a carga de trabalho às vezes dá uma pesada, você chega em casa [sic] à noite tá um nível de estresse altíssimo, ansiedade altíssima, mas nada que não dê pra controlar [...] as cobranças, às vezes a cobrança é muito alta.

O estresse, de modo geral, é compreendido como "uma condição dinâmica na qual um indivíduo é confrontado por uma oportunidade, restrição ou exigência relacionada ao que ele deseja e pela qual o resultado é percebido como sendo tanto incerto quanto importante" (Robbins, 1994, p. 18). Desse modo, estresse é um processo pelo qual o organismo procura lidar com estímulos, os agentes estressores, que provocam tensão e ameaçam seu equilíbrio interno. Os agentes estressores são qualquer circunstância que amedronte, confunda ou excite uma pessoa; são as situações que liberam no organismo humano a reação de estresse e exige que o corpo se adapte a essa nova situação. Contudo, "o estresse sempre existiu! Ele é uma reação do organismo, quando esse entra na reação luta x fuga" (Bertoldi, 2013, p. 181). Enumo, Weide, Vicentini, Araujo e Machado (2020, p. 3) descreveu ainda que as reações aos estressores têm relação com sua severidade, duração e outras características como:

[...] tipo, permanência (agudo ou crônico), previsibilidade, rapidez de aparecimento (abrupto ou lento), flutuação e intensidade (fraco, moderado, forte, ambíguo). Dependem também de características do sujeito, como a idade, o gênero, as experiências prévias e o temperamento, dentre outras. Relacionam-se ainda às características do contexto, destacando-se a importância da rede de suporte social.

No ambiente de trabalho, tais características se agravam, uma vez que, com os avanços da tecnologia da informação, aumentaram a demanda por trabalhadores com múltiplas aptidões e a maior estima do trabalho em equipe gerou mudanças no modo de supervisionar (Ferreira \& Assmar, 2008). Essa nova forma de trabalho ocasiona diversas consequências, entre elas, o estresse:

A exigência de maior produtividade, associada à redução contínua do contingente de trabalhadores, à pressão do tempo e ao aumento da complexidade das tarefas, além de expectativas irrealizáveis e as relações de trabalho tensas e precárias, constituem fatores psicossociais responsáveis por situações de estresse relacionado ao trabalho (Ministério da Saúde \& Organização Pan-Americana da Saúde, 2001, p. 40).

No ambiente de trabalho, Ferreira e Assmar (2008, p. 21) definem o estresse ocupacional ou laboral como “expressões usadas para designar não somente o processo, mas também o conjunto de reações físicas e psíquicas provocadas pela vivência 
de condições adversas no ambiente organizacional". Esse contexto é notável na fala de E2:

A gente passa oito horas por dia, e eu, assim, não só oito, porque eu vou pra casa e o telefone ainda fica tocando, às vezes horário de almoço, à noite. Tudo o que acontece na empresa interfere na vida pessoal.

Por outro lado, E1 alega: "eu fiz dois anos de terapia [...] depois que eu fiz a terapia, hoje eu consigo separar bem a questão do trabalho com a minha vida”. A fala de E1 exemplifica uma boa relação com o estresse diário, que como já descrito, é uma reação do organismo, sendo importante saber lidar com os agentes estressores para que se consiga também adaptar-se aos momentos. Como abordado por Simonelli (2020, p. 2), "Enquanto os níveis moderados de estresse podem energizar um indivíduo para realizar suas tarefas respeitando requisitos como prazo e qualidade, por outro lado, o estresse não gerenciado tende a ser uma experiência perturbadora emocionalmente".

Algumas entrevistadas expressam o termo "estresse", como foi o caso de E2, E3, E5 e E11, entretanto, outras entrevistadas apesar de não usar o termo, descreveram sintomas causados por ele, como foi o caso de E1, E6, E8, E9 e E13. Os sintomas relatados se aproximam com os principais indicadores de ordens física, emocional, comportamental e cognitivo do estresse descrito por Enumo, et al. (2020, p. 3):

Os indicadores mais comuns de estresse e ansiedade são de ordem: (a) física, como dor de cabeça, aumento dos batimentos cardíacos, problemas de alimentação e de sono, úlceras, exaustão física; (b) emocionais, como tristeza, nervosismo, raiva, culpa, preocupação excessiva, perda de vontade e humor deprimido; (c) comportamentais, como irritabilidade, distanciamento, abuso de substâncias, violência; (d) cognitivos, como a perda de memória, dificuldade de concentração, dificuldade de tomar decisões.

A sintomatologia descrita por Enumo, et al. (2020) e relata pelas pessoas entrevistas muitas vezes é percebida como sintomas ora desassociados ao ambiente de trabalho e ora relacionados. E2 relacionou indicadores como "dor de cabeça, estresse, cabelo caindo, tudo e mais um pouco eu tenho certeza que tem a ver com o meu serviço, que é estressante", descreveu ainda que:

[...] às vezes o que todo mundo quer que faça tudo do jeito que eles querem, então acaba sendo muito estressante, e isso sim, eu acho que a saúde mental da gente, não física porque a gente não faz nada braçal, mas o estresse, as dores, são daí.

Igualmente, E3 também aponta alguns indicadores sentindo palpitação e tremores: "eu começo a tremer e quando eu começo a tremer eu sei que eu vou ficando nervosa. É, tipo, sintomas físicos mesmo que eu sinto: fico estressada eu começo a tremer, dá aquela palpitação. [...] em casa acontece também".

Outras duas entrevistadas que usaram o termo "estresse" se mostraram mais confortáveis com o assunto. E5 diz que "já melhorou muito" e que desestressa jogando futebol. Já E11 faz uma analogia descrevendo que tudo gera estresse: "Trabalho gera estresse, mulher gera estresse demais, casa, menino, dívida, dinheiro...”, indo ao encontro do que foi citado por Beltoldi (2013) de que o estresse sempre existiu e sempre vai existir por ser uma reação do organismo. Entretanto, Santos, Costa, Pinto, Franco, Coelho \& Sardinha (2021, p. 3) trazem o alerta:

[...] o estresse ocupacional contínuo pode acarretar prejuízos à saúde mental e física do trabalhador, tais como: hipertensão, diabetes, o desenvolvimento da síndrome metabólica, distúrbios do sono, enfermidades psicossomáticas, síndrome de bournout, depressão, uso de substâncias psicoativas, além de queda na produtividade, absenteísmo, insatisfação laboral e baixa qualidade de vida no trabalho.

Já entre as entrevistadas que não mencionaram o termo, entretanto narraram indicadores quando questionados sobre a 
saúde e a relação desta com a Empresa X, E1 descreve que já melhorou bastante, pois antes ela perdia o sono e tinha crises de ansiedade, e que hoje se sente bem melhor após fazer quase dois anos de terapia. Já E6, que ainda passa por essas situações, diz sentir “ansiedade, nervosa. Às vezes não consigo dormir [...], mas é de mim, não digo que a empresa traz isso pra mim" e descreve mais detalhado sobre essa ansiedade da seguinte forma:

[...] eu sou uma pessoa que geralmente não consigo me desligar tanto, entendeu? Se eu tenho uma coisa pra fazer [...] enquanto não resolver, não passar, eu não me desligo tanto, eu fico sempre preocupado, então até resolver a situação. Então, isso pra mim, eu acabo achando ruim, não é culpa do trabalho, mas eu mesma que sou desse jeito. Pra mim, eu preferiria sair daqui e se desligar, amanhã eu volto de novo, mas às vezes eu fico pensando, eu vou pra casa e fico pensando: "Tenho que fazer isso, tenho que fazer aquilo"; isso acaba, acho, que me afetando, não drasticamente, mas afeta um pouco no dia a dia.

Ela percebe que esses indicadores de ansiedade, como "não conseguir desligar", afetam ela no dia a dia, e justifica que não é a empresa que causa isso. Entretanto, pelo que já foi descrito anteriormente neste estudo, a necessidade de desenvolver novas aptidões e o trabalho em equipe para atender a nova forma de trabalhar são indicativos de ocasionar o estresse laboral. E8 também aponta que "às vezes você chega final do dia você tá esgotado, isso é meio que normal, né? Não vou falar pra você que não acontece comigo, acontece sim”, e finaliza sua narrativa enfatizando que não deixa que isto afete seu comportamento em casa e que sabe separar os dois ambientes, empresarial e domiciliar.

Quando questionada sobre a percepção da sua saúde, E7 disse que o trabalho dela não afeta sua saúde, porém ponderou “claro que um pouco o emocional, né? Porque a gente trabalha o corpo, mas trabalha a mente." E ainda que isso gera um pouco de ansiedade: “o cansaço da mente e tal. Eu não vejo como um problema de saúde", e que nos dias em que fica algo sem fazer, fica lembrando disso em casa pensando "devia ter feito tal coisa". Percebe-se que, mesmo afirmando que o trabalho não afeta sua saúde, ele influencia o estado de ansiedade que ela apresenta posteriormente em casa.

E9 também traz alguns indicadores emocionais que descreve como: “desânimo, na vontade de não vir trabalhar, aquelas coisas que dá assim, meio deprê, né?", e complementa narrando que isso no passado foi ocasionado "por questões organizacionais de você achar que não é reconhecido o seu trabalho, essas coisas assim já aconteceu muito, [...] influenciava emocionalmente, [...] essas questões assim mais pra esse lado de desmotivação”. Essa fala demonstra o seu descontentamento com o ambiente de trabalho, pois, como abordado pelo Ministério da Saúde e Organização Pan-Americana da Saúde (2001, p.161), “frequentemente, o sofrimento e a insatisfação do trabalhador manifestam-se não apenas pela doença, mas nos índices de absenteísmo, conflitos interpessoais e trabalho extra".

Nesse aspecto questiona-se até onde a comunicação empresarial e o relacionamento com colegas e superiores influenciaram para que este indicador fosse percebido pela E9 a ponto de ela descrever esta desmotivação quando questionada sobre a influência dos acontecimentos da empresa sobre sua saúde. Visto que ela descreveu anteriormente que percebia a comunicação empresarial como "péssima" e que "não funciona", tornando perceptível o seu descontentamento não só com a comunicação, quanto com a falta de reconhecimento do seu trabalho pela Empresa X.

Já E13 descreveu que sente muita ansiedade e que não tem muita disposição para fazer as coisas e associou a sensação de desgaste e cansaço ao precisar ficar cobrando outras pessoas coisas que não cabem a ela. Descreve enfática "Muito desgastante pra mim! Eu fico muito cansada, mentalmente assim, porque eu podia estar ocupando o meu tempo, a minha cabeça mesmo, preocupação com outras coisas, e eu tô cobrando as pessoas coisa que nem cabe a mim". Tal fala evidencia que o aspecto de ruptura de informação, outrora elucidado neste estudo, também influencia na percepção de desgaste físico e mental. 


\section{Considerações Finais}

Com a evolução tecnológica e os rearranjos sociais das últimas décadas, o ambiente empresarial precisou se adequar para atender às novas demandas e, com isso, seus colaboradores também precisaram se desenvolver em várias dimensões. Este estudo centrou-se em analisar o ambiente organizacional com foco na comunicação empresarial e sua relação com a saúde do colaborador.

Ao analisar a percepção dos colaboradores quanto a comunicação empresarial, é notável que, majoritariamente, as pessoas entrevistadas a percebem como positiva, de um modo geral. Apesar dessa visão positiva, foi descrito como esta comunicação sofre rupturas quanto a quebra do fluxo que a informação deveria seguir, "pulando" algumas pessoas no meio do caminho.

Levando-se em consideração quando os colaboradores precisavam se opor ou contestar, houve dualidade. Uma parcela das pessoas entrevistadas se mostrou desconfortável ao precisar se opor, corrigir ou contestar algum colega de trabalho. Enquanto outras manifestaram-se tranquilas em fazer isso. Ainda tiveram algumas pessoas que, apesar de se sentirem desconfortáveis, afirmaram que o fariam pensando no bom andamento da empresa.

Pela observação dos aspectos analisados em relação a autopercepção da saúde dos colaboradores e relação da mesma com a comunicação empresarial, nota-se que algumas pessoas observam que há relação do ambiente empresarial com a sua saúde. Enquanto outras afirmam não ter relação, apesar de descrever indicadores que apontam níveis de estresse laboral perceptível. Várias entrevistadas fizeram menção aos termos "estresse" e "ansiedade" quando questionados sobre como percebiam sua saúde, deixando elucidado a relação que elas percebem entre os termos e o que foi questionado.

Tendo em vista os aspectos acima observados, faz-se necessário abordar que este estudo visou elucidar tais informações a fim de possibilitar uma maior compreensão do ambiente empresarial com foco em sua comunicação empresarial e sua relação com a saúde dos colaboradores em uma empresa específica, compreendendo essa relação de modo amplo neste ambiente. Cabe a reflexão de até onde uma comunicação vista como positiva por seus membros, possuindo um livre acesso entre todos os setores, também foi apontada como geradora de ansiedade e estresse.

Após a presente análise, sugere-se que novos estudos sejam realizados para que o assunto possa ser mais bem aprofundado com metodologias qualitativas e também quantitativas para que se possa comparar um número maior de empresas em seus aspectos que se assemelham ao cenário encontrado na presente pesquisa, podendo, assim, elucidar se esta relação entre comunicação empresarial e a saúde do colaborador podem estar mais interligadas do que o que apontado neste estudo ou se tal hipótese não se confirma.

\section{Referências}

Bardin, L. (2011). Análise de conteúdo. São Paulo: Edições 70.

Beltrão, O. \& Beltrão, M. (1993). Correspondência: Linguagem \& Comunicação. São Paulo: Atlas.

Bertoldi, A. D. (2013). Psicologia organizacional e do trabalho. Indaial: Uniasselvi.

Bianco, M. H. B. C. (2000). Construção da autonomia do enfermeiro no cotidiano: um estudo de caso etnográfico sob o referencial teórico de Agnes Heller. Florianópolis: Edusc.

Bordenave, J. E. D. (1995). O que é comunicação. São Paulo: Brasiliense.

Brum, A. M. (2000). Um olhar sobre o marketing interno. São Paulo: L\&PM.

Bueno, W. C. (2003). Comunicação empresarial: teoria e pesquisa. Barueri: Manole.

Cardoso, A. C \& Morgado, L. (2019). Trabalho e saúde do trabalhador no contexto atual: ensinamentos da Enquete Europeia sobre condições de trabalho. Saúde e sociedade, 28(1), 169-181. doi:10.1590/S0104-12902019170507. 
Chiavenato, I. (2000). Introdução à teoria geral da administração. Rio de Janeiro: Campus.

Chiavenato, I. (2005). Comportamento organizacional: a dinâmica do sucesso nas organizações. Rio de Janeiro: Elsevier.

Cortes, T. P. B. B., Nunes, M. F. H., Ernesto, T. S., Martins, A. O., Souza, C. H. M. (2018). A importância da comunicação para a promoção da saúde na sociedade do conhecimento. Temas em Saúde, 18(4), 122-142. https://temasemsaude.com/wp-content/uploads/2018/12/18408.pdf

Enumo, S. R. F., Weide, J. N., Vicentini, E. C. C., Araujo, M. F., \& Machado, W. L. (2020). Enfrentando o estresse em tempos de pandemia: proposição de uma Cartilha. Estudos de Psicologia, 37, e200065. doi:10.1590/1982-0275202037e200065

Ferreira, M. C. \& Assmar, E. M. L. (2008). Fontes ambientais de estresse ocupacional e Burnout: tendências tradicionais e recentes de investigação. In Tamayo, A. (Org.). Estresse e cultura organizacional (pp. 21-73). São Paulo: Casa do Psicólogo.

Kotler, P. (1998). Administração de marketing. São Paulo: Atlas.

Kunsch, M. K. (2006). Comunicação organizacional: conceitos e dimensões dos estudos e das práticas. In Marchiori, M. (Org.). Faces da cultura e da comunicação organizacional (pp.167-190). São Paulo: Difusão Editora.

Kyrillos, L. \& Jung, M. (2015). Comunicar para liderar. São Paulo: Contexto.

Lent, R. (2005). Cem bilhões de neurônios. São Paulo: Atheneu.

Lima, M. D. C. (2015). As dimensões da Comunicação Organizacional: um olhar sobre o Instituto Ler para Crescer. Dissertação de Mestrado, Universidade Federal do Amazonas, Manaus, AM. https://tede.ufam.edu.br/handle/tede/4841

Lück, H. (2010). Gestão da Cultura e do Clima Organizacional da escola. São Paulo: Vozes.

Marchiori, M. (2011). Cultura e Comunicação Organizacional: um olhar estratégico sobre as organizações. São Paulo: Difusão Editora.

Marques, J. R. (2018). A importância da comunicação eficaz nas organizações. from https://www.ibccoaching.com.br/portal/rh-gestao-pessoas/importanciacomunicacao-eficaz-organizacoes

Matos, G. G. (2004). Comunicação sem complicação: como simplificar a prática da comunicação nas empresas. Rio de Janeiro: Elsevier.

Ministério da Saúde \& Organização Pan-Americana da Saúde. (2001). Doenças relacionadas ao trabalho: manual de procedimentos para os serviços de saúde - Série A. Normas e Manuais Técnicos - n. 114. Brasília: Ministério da Saúde do Brasil.

Montes, E. (2020). Gerenciamento das Comunicações. São Paulo: Kindle.

Neiva, F. (2018). Comunicação das Organizações: um olhar sobre a importância da comunicação interna. Media \& Jornalismo, 18(33), 61-73. doi:10.14195/2183-5462_33_4

Oliveira, E. J., Damião, W. S., Oliveira, E. D., \& Nogueira, G. A. F. (2020). O papel estratégico da comunicação corporativa. In Oliveira, E. J., Damião, W. S., \& Oliveira, E. D. (Org.). Gestão estratégica (pp. 11-22). Belo Horizonte: Poisson. doi:10.36229/978-65-86127-47-8.CAP.01

Resolução $\mathrm{n}^{\circ}$ 510, de 7 de abril de 2016. (2016). Trata sobre as diretrizes e normas regulamentadoras de pesquisa em ciências humanas e sociais. Conselho Nacional de Saúde. http://conselho.saude.gov.br/resolucoes/2016/Reso510.pdf

Robbins, S. P. (1994). Comportamento organizacional. Rio de Janeiro: LTC.

Santos, P. W. S., Costa, M. A., Pinto, R. G. S., Franco, K. S., Coelho, R. F. Santos, Y. M. R. \& Sardinha, A. H. L. (2021). Análise da ansiedade e do estresse laboral em profissionais da Atenção Primária à Saúde. Research, Society and Development, 10(6), e26210615763. doi:10.33448/rsd-v10i6.15763

Silva, L. F. \& Machado, M. D. (2017). Comunicação empresarial. São Paulo: Editora Senac.

Simonelli, L. (2020). Estresse ocupacional e alternativas de intervenção: um estudo bibliométrico. Research, Society and Development, 9(3), e67932401. doi:10.33448/rsd-v9i3.2401

Souza, A. S., Alves, G. G., Câmara, S. G., Aerts, D., H., A., \& Gedrat, D. C. (2019). Percepção de saúde e felicidade entre trabalhadores da Estratégia Saúde da Família de um município do sul do Brasil. Aletheia, 52(2), 108-121. http://pepsic.bvsalud.org/scielo.php?script=sci_arttext\&pid=S141303942019000200009\&lng=pt\&tlng=pt

Takahashi, R. T. \& Pereira, L. L. (1991). Liderança e Comunicação. Rev. Esc. Enf. USP, 25(2), 123-135. https://www.scielo.br/j/reeusp/a/pZmxtbwcJ5PMpdJgJmhMXBv/?format=pdf\&lang=pt

Torquato, G. (1991). Cultura, poder, comunicação e imagem: fundamentos da nova empresa. São Paulo: Pioneira. 